\title{
Secondary EL Teachers' CPD: Present Practices and Perceived Needs
}

\author{
Abdul Rouf and Abdul Rashid Mohamed
}

\begin{abstract}
The present paper reports a study that aimed to explore secondary school (SS) English language (EL) teachers' present practices of and perceived needs for continuing professional development (CPD) in Bangladesh. In $21^{\text {st }}$ century worldwide educational settings, 'change' is the only constant trend. Consequently, EL teachers need to be continuously updated in their professional knowledge base and skills. They must be engaged in effective CPDs to keep abreast of innovations in language learning and teaching for their own career development and better learning outcomes for learners. Using a semi-structured questionnaire qualitative data was collected from 10 secondary EL teachers. The findings show that overall scenario of SS EL teachers' CPD is not encouraging. The paper also discusses some implications for teachers' professional learning.
\end{abstract}

Key words: Secondary EL Teachers, CPD, Practices, Needs

\section{Introduction}

In research literature, teachers' continuing professional development (CPD) has been defined in various ways. CPD is used as an umbrella term to indicate professional growth, learning, and development of teachers. Hayes (2014), for example, explicated CPD as a life-long, many-sided experience that occurs inside or outside the workplace and covers both teachers' professional and personal life. In a broader sense, CPD refers to diverse educational experiences connected to an individual's work. Professionals take part in CPD activities to learn and apply new knowledge and skills that help improve their performance (Mizell, 2010).
According to Richards (2017), English is accorded a special position in many parts of the world, which necessitates supply of a good number of quality English language (EL) teachers; Bangladesh is no exception. Most of the secondary school (SS) EL teachers in Bangladesh are non-native English-speaking teachers (NNESTs). They need continuous training for keeping themselves updated in their knowledge base and skills. In this context, CPD can play an important role in teachers' professional development (PD). As teaching is not an inert profession, CPD would create opportunities for them to be engaged in reflective practice, to enhance knowledge and skills, and to collaborate with other teachers (Davidson, Dunlop, Soriano, 
Kennedy, \& Phillips, 2012). Mizell (2010, p. 18) commented, "Good teaching is not an accident." According to him, EL teachers are supposed to engage themselves in an ongoing cycle of PD, both at organizational and personal level.

As teachers exert much influence on learners' learning and achievements, PD of teachers is getting more attention internationally (Ambler, 2016; Kennedy, 2005). CPD activities improve teachers' instructional practices in classrooms and help students perform and achieve better results (Barlow et al. 2014 cited in M. S. Zein, 2016). Moreover, PD can contribute a lot to the improving performance of schools (Fraser, Kennedy, Reid, \& McKinney, 2007). Without effective professional training, teachers' knowledge and skills are not enhanced. They become outdated in their knowledge base and classroom practices; thus, learners suffer significantly.

Teachers engage themselves in CPD not only to improve the performance and results of their schools and learners but also to gain professional knowledge and skills for their career development (Evans, 2014). Teacher Educators (TEs) and other stakeholders should not always try to establish a direct link between learners' result and teachers' trainings, as the basic target of teachers' PD is to enhance their professional competencies. One common problem is the education bureaucracy's expectation to see immediate impact of teachers' PD on learners' learning outcomes (Narkar, 2013).

In $21^{\text {st }}$ century educational settings, change occurs rapidly, making teachers' engagement in CPD obligatory. There are fast and unanticipated changes in knowledge, teaching-learning and technology (Jamil, Razak, Raju, \& Mohamed, 2011). CPDs help teachers keep updated in their knowledge and skills, so they can teach young learners effectively (S.
Zein, 2015). They cannot become fossilized as they continue teaching new learners with the latest ideas. They must move forward with time and equip themselves with knowledge and skills demanded by contemporary society and learners. Faced with ever changing challenges and demands, CPD has become more significant as this is the only way for teachers to remain efficient (Padwad \& Dixit, 2013).

Teachers are supposed to be lifelong learners and continuously update themselves (Ambler, 2016). It is crucial for teachers to comprehend that they are learners first, then teachers. This instinct of continuous learning and development must be rooted in every teacher. Once teachers themselves are updated in their professional knowledge base and practices, they are morally in the right position to teach their learners (Alexandrou \& Swaffield, 2012). They also need PD for providing guidance and direction to novices in the profession, and for avoiding burnout; CPD then helps augment teachers' professional capacity by highlighting their weak areas and recommending necessary trainings (Khan, 2009). Moreover, when teachers involve themselves in PD activities, teacher leadership is created among them and they can apply teachers' agency. Exercise of teachers' agency positively impacts learners' learning and achievements (Alexandrou \& Swaffield, 2012).

This paper is organized in six sections. It starts with a brief introduction to the topic of the study and gives its background; the second part presents a concise review of relevant literature; the third part is about methodology used; the fourth and fifth parts depict the findings and discussion respectively. Finally, it ends with presenting some implications for EL teachers' CPD, limitations of the study and suggestions for further research. 


\section{Literature Review}

Ifanti and Fotopoulopou (2011) studied inservice primary teachers' concerns and thoughts regarding professionalism and PD in Greece. The respondents believed that CPD would certainly enhance teachers' professionalism and the training model is the best option for PD. They mentioned that teachers' knowledge and skills, as well as their willingness to keep up with the current educational issues are key factors for professionalism and PD.

Narkar (2013) investigated the impact of a District Centre (DC) in Nellore, Andhra Pradesh, India on EL teachers' training. The teachers claimed that CPD trainings exposed their weak areas as teachers, and they could develop language proficiency and other skills through study and practice in a collaborative way. In the postintervention phase, when the DC was closed, the teachers organized themselves by forming English Teachers' Association (ETA) to continue their PD. Thus, an initial top-down process resulted into bottom-up initiatives taken by the teachers themselves.

In a study by McMillan, McConnell, and O'Sullivan (2014) in Ireland, teachers opined that teachers themselves are mainly responsible for their PD. They mentioned personal interest, career progress and practice improvement as the main personal motivating factors for attending CPD. For school-related factors, feedback from colleagues and school policy were the main factors. System-wide motivation factors included the mandatory nature of PD programs as organised by schools or subject organizations. They also pointed out some barriers to CPD such as schools' lack of interest, teachers' financial constraint, and limited training budgets in schools. As CPD is for teachers, policy makers should listen to teachers' voices on CPD.
S. Zein (2015) found that most of the elementary EL teachers in Indonesia did not have any exposure to in-service training. Another setback reported was the mismanagement of training programs organised by government training institutions. The content of the training programs was selected by the education bureaucrats, who ignored the practical aspects of teaching English and highlighted theoretical features. Training participants' selection then was not transparent, rather "based on favoritism and connection" ( $p$. 431). While selecting teachers for training, teachers of low status schools were often ignored.

Yook and Lee (2016) surveyed Korean EFL teachers' perceptions of how teacher education programs affected their classroom teaching. The findings show that pre-service teacher education programs had little impact on teachers' classroom practices as these programs were predominantly theory-oriented. On the other hand, teachers reported that inservice teacher education trainings were more helpful as they increased their speaking skills and knowledge of new methods for EL teaching. In addition, teachers mentioned that the washback effect of Korea Scholastic Aptitude Test was a barrier to implementing ideas they learned from the trainings as they had "to teach to the test" (p. 10).

Through a case study, Nawab (2017) reported that after attending an in-service course, there were some positive changes in the attitude and practices of the trainee teacher in rural Pakistan. However, gradually the teacher lost his enthusiasm for various reasons, such as lack of resources and space, time constraint, workload, no encouragement from other teachers, no collaboration and support, and lack of logistic support from education officials; consequently, the class went back to previous practices. 
Power, Shaheen, Solly, Woodward, and Burton (2012) looked into effectiveness of English in Action's (EIA) school-based teacher development (SBTD) initiative in Bangladesh. EIA provided teachers with educational mobile technology, innovative materials, and schoolbased support, both by school and project experts. Because of the interventions, primary and secondary EL teachers' class performance improved, and they used English more frequently inside classes. The writers argued that SBTD may play an active role in enhancing teachers' performances.

Studies reviewed above were carried out in Greece, India, Ireland, Indonesia, Korea, Pakistan, and Bangladesh and focused on different aspects of CPD. However, very few studies are available on SS EL teachers' CPD in Bangladesh. The present study addressed the gap in existing literature as far as SS EL teachers' engagements in CPDs and their perceived needs are concerned in Bangladesh.

\section{Research Methodology}

The study reported here was carried out using a multiple case-study approach following the qualitative paradigm (O'Brien, Harris, Beckman, Reed, \& Cook, 2014). Among different approaches of qualitative research paradigm, researchers often choose case studies for conducting their research (Yazan, 2015).

\section{Research Objective and Question}

The overall research objective of this study was to explore SS EL teachers' present practices of and perceived needs for CPD. Consequently, it addressed the following research question:

- What are the present practices of and perceived needs for secondary EL teachers' continuing professional development (CPD)?

\section{Participants}

Following a purposive sampling technique, 10 EL teachers were selected from three SS, two non-government and one government in Dhaka. Three teachers were selected from the government SS and the rest $(n=7)$ were from non-government SS. Initially, the participants were informed about the objective of the study. They were briefed on how their privacy would be preserved. They could withdraw from the study whenever they wanted (Chenail, 2011; Hamid, 2010; Praag \& Sanchez, 2015). To ensure anonymity, alpha-numeric identity (T1T10) has been used for all participants involved in this study (Ambler, 2016; M. S. Zein, 2016;).

Procedures for Data Collection and Analysis

One-to-one individual interviews were conducted with the EL teachers to collect in-depth data by using a semi-structured interview (Merriam, 1988). All the interviews were audio-taped and securely stored. Collected qualitative data was analysed using thematic analysis (TA) as proposed by Braun and Clarke (2006). As the interviews were conducted in Bengali, used excerpts have been translated by the first author; however, a few excerpts are directly quoted from teachers' interviews.

\section{Findings}

\section{Limited opportunities and sporadic nature of CPD}

There are limited opportunities for SS EL teachers' institutional PD. Directorate of Secondary and Higher Education supervises SS teachers' CPD through its affiliated bodies such as National Academy for Educational Management (NAEM) and Teacher Training Colleges (TTCs). Thana Education Officer (TEO) does the field work 
to decide who will get CPD trainings in consultation with respective school authorities. Teachers have attended 1-4 CPDs organized by NAEM, TTC, projects like English in Action (EIA), and English Language Teaching trained on that; there is hardly any followup training. Thus, most of the CPDs are project based with a top-down approach.

Table 1. Relevant information on the participating EL teachers

Improvement Project (ELTIP). These CPDs predominantly focus on teaching methodology; teachers are taught how they can implement a lesson successfully.

In CPDs teachers learn how to deliver a lesson effectively. (T2)

Present organizational CPDs are designed by foreign experts and education officials, and delivered off-site by external experts. Thus, a top-down approach is followed for teachers' institutional CPD. Teachers pointed out that the foreign experts are not familiar with the social and classroom realities in Bangladesh.

CPDs are designed by foreign experts; they do not understand the realities of our country. We work according to our realities and standards of school. (T3)

\begin{tabular}{|l|l|c|l|l|}
\hline Teacher & Gender & $\begin{array}{c}\text { Teaching } \\
\text { Experience } \\
\text { (Years) }\end{array}$ & $\begin{array}{c}\text { School by } \\
\text { Management }\end{array}$ & \multicolumn{2}{|c|}{$\begin{array}{c}\text { Number } \\
\text { of CPD } \\
\text { Attended }\end{array}$} \\
\hline T1 & Female & 2 & Non-government & 12 \\
\hline T2 & Male & 2 & Non-government & 17 \\
\hline T3 & Male & 2 & Non-government & 26 \\
\hline T4 & Female & No CPD & Non-government & 3 \\
\hline T5 & Female & 1 & Non-government & 35 \\
\hline T6 & Male & 3 & Government & 8 \\
\hline T7 & Male & 4 & Government & 24 \\
\hline T8 & Male & 3 & Government & 14 \\
\hline T9 & Male & 2 & Non-government & 22 \\
\hline T10 & Female & 3 & Non-government & 22 \\
\hline
\end{tabular}

Rare personal initiatives for CPD

As these CPDs are pre-planned, individual EL teachers' professional needs are not taken into consideration. Teachers argued that it is difficult to arrange school-based CPDs as schools do not have experts to train teachers. They also have to develop training facilities.

CPDs can be arranged in schools but the problem is that we do not have experts and technological facilities in schools.

However, some schools arrange in-house training for teachers on ICT by internal experts who were earlier trained by external experts.

One striking reality is that institutional CPDs are sporadic, not continuous. When a new project is launched, changes are made in curriculum and policies, and teachers are

Apart from the meager institutional initiatives, teachers take rare personal initiatives for PD. Teachers do not use systematic 'reflection' as a strategy for enhancing their classroom performance. They are not engaged in research as the 'research culture' is missing in schools. Moreover, they do not read relevant journals as part of their professional learning. Teachers even do not use online materials for their professional learning. They mentioned that they cannot take personal initiatives for PD because of intense workload and lack of time.

I am not engaged in research; I do not read academic journals. The main obstacles are lack of time and low salary. To earn additional money I do private tutoring. (T9) 


\section{Difficulty with implementing ideas learned from CPDs}

Teachers cannot easily implement ideas they learn from CPDs as they face different difficulties in classrooms. First, the number of students - around 60 or more per class makes it difficult for teachers to manage their classrooms, let alone implement ideas learned from CPDs.

Training is one aspect but reality is different. We cannot implement ideas from CPDs. Even many ideas are not fruitful for our country. For example, class size; CPD trainers advocate that the number of students in a class should be 30 but we have 70 or more students in our classes. (T8)

In addition, according to the teachers, both learners and their guardians are interested in good grades not in learning language skills. This makes teachers focus on the tests, ignoring all methodological innovations they learn in CPDs.

The examination system is different. If we follow all those techniques, we will then not be able to complete the syllabus. The guardians want good result but we want to teach language skills .....there are divergences. (T9)

Teachers learn to make their class participatory and communicative. However, the prevailing examination system does not encourage communicative classroom environment. Moreover, the fixed seating arrangement in classrooms makes it difficult for teachers to carry out group work and pair work.

We cannot do group work and pair work because of the seating arrangement; doing group work and pair work kills our time and we cannot finish the syllabus. If we cannot complete the syllabus, guardians will complain against us. (T1)

The class duration of 30-40 minutes with 60 or more students is not adequate to carry out effective lessons.

Within the limited time we cannot
deliver effective lesson. Most of our
classes have 60 or 70
students.... Managing these large
classes, we cannot use all techniques. For
example, I cannot evaluate students in
my class. (T10)

\section{Collaboration with other Teachers}

EL teachers work as isolated islands as they do not collaborate with one another. Teachers have professional organizations, but these organizations try to materialize different demands such as salary hike, nationalization of jobs; however, they do not take any initiative for members' PD. Moreover, teachers never visit other schools for professional learning.

We have cordial relationships among ourselves but we do not collaborate on professional development. We do not visit other schools for professional learning. ............ Teachers' organizations work only for materializing teachers' professional demands. (T6)

Teachers mentioned that school authorities have a positive attitude towards teachers' CPD and when there are arrangements, school authorities send them for off-site CPDs. However, some schools do not send teachers for CPDs as this hampers the school routine. In some cases, school authorities do not either encourage or discourage teachers to attend CPDs. 


\section{Future CPDs for Teachers}

EL teachers claimed that they need more CPD activities particularly on ICT and language skills. They argued that institutionally there should be more opportunities for CPD. One aspect that teachers repeatedly mentioned is that CPD activities must be continuous not sporadic as is the present practice. They opined that there should be arrangement for teachers' annual CPD.

It (CPD) should continue and all the teachers should be included there and annually teachers should be trained. (Directly quoted from T2)

\section{Challenges to Teachers' CPD}

SS EL teachers face different challenges with regard to attending CPD. One vital barrier is their lack of time as they teach on an average six classes per working day. Frequently, they also teach proxy classes when concerned teachers are on leave or busy with other duties.

No teacher should have more than 20 classes per week. Some teachers have 26 classes per week. (T10)

They also pointed out lack of adequate institutional opportunities for taking part in CPDs. Moreover, many of them are busy with private tutoring and coaching to earn additional money as the salary they get, according to them, is not enough for maintaining their family expenses. However, teachers agreed that engagement in private tutoring and coaching kills much of their time that they could invest in CPD activities.

Many teachers do not see teaching as a profession rather as any other job. This mindset does not encourage teachers to take initiatives for further professional learning.

.....sometimes I think whether I am an employee or a teacher. These feelings work in me. (T7)

I think we learned there and left those things at the training spot. For some days we tried to use them in classrooms, then no more implementation. (T5)

\section{EL Teachers' Perceptions of and Commitment to CPD}

Teachers believe that they should be regularly updated, and CPDs enhance their knowledge, skills, and confidence.

Teachers should be updated through professional development. As things are changing rapidly, e.g. technology, teachers cannot lag behind. CPD enhances teachers' knowledge, skills and confidence. I learned a lot from CPD. I had to do presentation in English in front of other teachers and trainers. (T1)

It (CPD) is very effective as I will learn many things from CPDs. (T4)

They consider CPDs as indispensable parts of their professional life, not as additional aspects. When teachers are required to go on continually teaching classes without any professional training, they lose their motivation.

Sometimes classroom teaching becomes monotonous; training can enhance teachers' motivation. (T6)

Teachers also highlighted that there should be monitoring after they attend CPDs to ensure that teachers implement new ideas from CPD in their classrooms. They also 
opined that CPDs may be school-based; both internal and external experts can facilitate school-based CPDs. Frequently, teachers mentioned that CPDs have to be regular.

As suggested by the name, CPD has to be continuous. (T7)

Teachers reiterated their commitment to PD; however, they mentioned time constraint and workload as factors that inhibit their professional learning.

\section{Discussion}

Secondary EL teachers do not get adequate opportunities for professional learning. Ambler (2016) argued that teachers have to be lifelong learners, and they need to be updated continuously. At present teachers' $\mathrm{CPD}$ is defined in a narrow sense. Some teachers have attended four CPDs whereas some are yet to attend any official CPDs. An effective monitoring system to equally distribute CPDs among teachers is missing. Moreover, the present CPD trainings exclusively focus on teaching methodology instead of taking a holistic approach. Teachers believe that they need CPDs for their professional growth, and CPDs enhance their knowledge, skills and confidence (Ifanti \& Fotopoulopou, 2011; Narkar, 2013; Nawab, 2017).

A top-down approach is followed for teachers' institutional CPD. From design to delivery, foreign experts and education bureaucrats play a big role in teachers' PD, assigning teachers a marginalized role. As CPDs are arranged for teachers, their voices must be heard while making decisions on professional learning (McMillan et al., 2014). EL teachers should be encouraged to take bottom-up initiatives for CPD as has been done by teachers in Nellore, Andhra Pradesh, India (Narkar, 2013). The problem with foreign experts is they are not familiar with the social contexts and classroom realities in Bangladesh. Moreover, external experts focus on theoretical knowledge, following a knowledge transmission model of CPD (S. Zein, 2015).

SS in Bangladesh usually do not take any initiatives for teachers' PD. In Malaysia, schools are encouraged to conduct in-house PD programs for improving teachers' knowledge and practices according to their needs (Jamil et al., 2011). Schools can arrange in-house CPDs for teachers by both internal and external experts. Schools have to groom their own experts and develop logistic facilities for training. Important lessons can be learnt from English in Action's (EIA) school based teacher development (SBTD) initiative in Bangladesh (Power et al., 2012). EIA facilitated teachers' school-based PD by involving experts from both schools and their project. This project had a positive impact on primary and secondary EL teachers' classroom performance and their use of English.

In addition, EL teachers lack personal initiatives for their PD. They are now totally dependent on organizational CPDs. In a developing country like Bangladesh, teachers should be encouraged to take responsibility for their PD. Indeed, teachers themselves should be mainly responsible for their PD (McMillan et al., 2014). For updating their knowledge skills, EL teachers need CPDs both at organizational and personal levels (Mizell, 2010). If teachers do not take personal initiatives like researching, reading journals, using online materials, attending conference, workshop, and seminar for PD, they will go on 
teaching in traditional ways. This echoes the significance of the comment by Ur (1996), who commented that "it has been said that teachers who have been teaching for twenty years may be divided into two categories: those with twenty years' experience and those with one year's experience repeated twenty times" (p.317). Because of workload and lack of time, teachers cannot attend CPDs; however, many teachers are involved in private tutoring and coaching.

Teachers also hardly collaborate with one another on PD. They just see themselves as employees, not as professionals. This mindset is a major obstacle for collaboration among teachers. Through collaboration, teachers can easily share their knowledge with one another. Only teaching the best practice in isolation will not work; rather, CPD practices need to be connected to teachers' and learners' everyday classroom contexts (DarlingHammond \& McLaughlin, 1995). There are many professional organizations of teachers but these organizations do not work for teachers' PD. Their activities are limited to materializing different jobrelated demands from the government such as salary hikes.

Teachers face various problems when they try to implement ideas and techniques they learn from CPDs. One main barrier is class size with more than 60 learners. Teachers get only 30-40 minutes to complete a lesson. Moreover, learners and guardians are more interested in passing the national exams with good grades. Thus, because of the wash-back effect of national exams, teachers are sometimes compelled "to teach to the test" (p. 10), ignoring language skill practices in classrooms (Yook \& Lee, 2016). Teachers categorically mentioned that the prevailing examination system in Bangladesh does not encourage a communicative classroom environment.

\section{Implications for SS EL Teachers' CPD}

Based on the findings of the present study, the authors would like to put forward some suggestions for policymakers, CPD designers, school authorities, and EL teachers:

a) More institutional CPDs need to be arranged for secondary EL teachers.

b) An effective monitoring system should be in place to ensure that all EL teachers get PD trainings, and teachers implement ideas and techniques they learn from PD.

c) While designing CPDs for EL teachers, teachers' voices must be heard.

d) Along with the present off-site CPDs, schools must arrange in-house CPDs. Each school should build a team of teachers for managing CPDs.

e) EL teachers must take personal initiatives for PD.

f) More collaboration on PD is needed among teachers.

g) Teacher organizations have to develop mechanisms for their members' PD.

h) It is vital to gradually change classroom realities: seating arrangement, class size, and class duration for effective implementation of ideas from CPD. 
i) Wash-back effect of national exams should not dominate classroom English teaching-learning practices.

j) For providing effective and necessary CPDs, it is fundamental to carry out a needs-analysis among EL teachers before designing any PD program.

\section{Limitations of the Study and Suggestions for Further Research}

Case studies do not target generalizations of findings; future researchers should work with a larger sample of EL teachers so that the findings can be generalized. This study then used samples only from schools in Dhaka; interested researchers can work with teachers from different areas of Bangladesh. Future studies on teachers' PD should involve other stakeholders such as policymakers, CPD designers, teacher trainers, and school authorities.

\section{Conclusion}

SS EL teachers play a significant role in imparting quality L2 education for learners in Bangladesh. To ensure quality classroom instruction and teachers' PD, there should be a mechanism in place to deliver effective CPDs. As UNESCO (1996 cited in Nawab, 2017) recommended, one-time pre-service training cannot prepare teachers for their whole career as new ideas and practices influence teaching-learning frequently. Teachers are supposed to try constantly to keep abreast of emerging trends and techniques by attending ongoing in-service trainings. All modern educational reform initiatives emphasize quality PD as it has become obvious that the quality of schools cannot surpass that of the teachers and officials who work there (Guskey, 2010).

\section{Acknowledgement}

The study reported here was funded through a GA scheme by Institute of Postgraduate Studies (IPS), Univesiti Sains Malaysia.

\section{References}

Alexandrou, A., \& Swaffield, S. (2012). Teacher leadership and professional development: Perspectives, connections and prospects. Professional Development in Education, 38(2), 159-167. doi: 10.1080/ 19415257.2012.657557

Ambler, T. B. (2016). The day-to-day work of primary school teachers: A source of professional learning. Professional Development in Education, 42(2), 276289. doi: http:/ / dx.doi.org/10.1080/ 19415257.2014.998343

Chenail, R. J. (2011). Interviewing the investigator: Strategies for addressing instrumentation and researcher bias concerns in qualitative research. The Qualitative Report, 16(1), 255-262.

Darling-Hammond, L., \& McLaughlin, M. W. (1995). Policies that support professional development in an era of reform. Phi Delta Kappan, 76(8), 597604.

Davidson, G., Dunlop, F., Soriano, D. H., Kennedy, L., \& Phillips, T. (2012). Goingforward: continuing professional eevelopment for English language teachers in the UK. UK: British Council.

Evans, L. (2014). Leadership for professional development and learning: Enhancing our understanding of how teachers develop. Cambridge Journal of Education, 44(2), 179-198. doi: 10.1080/ $0305764 x .2013 .860083$ 
Fraser, C., Kennedy, A., Reid, L., \& McKinney, S. (2007). Teachers' continuing professional development: Contested concepts, understandings and models. Journal of In-service Education, 33(2), 153-169. doi: 10.1080/ 13674580701292913

Guskey, T. R. (2010). Professional development and teacher change. Teachers and Teaching, 8(3), 381-391. doi: 10.1080/135406002100000512

Hamid, M. O. (2010). Fieldwork for language education research in rural Bangladesh: Ethical issues and dilemmas. International Journal of Research $\mathcal{E}$ Method in Education, 33(3), 259-271. doi: 10.1080/ 1743727x.2010.511714

Hayes, D. (2014). Overview- Innovations in continuing professional development: Sector-wide, institutional and personal perspectives. In D. Hayes (Ed.), Innovations in the continuing professional development of English language teachers (pp. 5-15). London: British Council.

Ifanti, A. A., \& Fotopoulopou, V. S. (2011). Teachers' perceptions of professionalism and professional development: A Case Study in Greece. World Journal of Education, 1(1), 40-51.

Jamil, H., Razak, N. A., Raju, R., \& Mohamed, A. R. (2011). Teacher Professional Development in Malaysia: Issues and Challenges. CICE Series, 4(2), 85-102.

Kennedy, A. (2005). Models of continuing professional development: A framework for analysis. Journal of Inservice Education, 31(2), 235-250.

Khan, R. (2009). Developing Professionally. The Dhaka University Journal of Linguistics, 1(2), 169-180.

McMillan, D. J., McConnell, B., \& O'Sullivan, H. (2014). Continuing professional development - why bother? Perceptions and motivations of teachers in Ireland. Professional Development in Education, 42(1), 150$167 . \quad$ doi: 10.1080/ 19415257.2014.952044

Merriam, S. B. (1988). Case study research in education: A qualitative approach. San Francisco:USA: Jossey-Bass Publishers.

Mizell, H. (2010). Why professional development matters. In V. V. Frank (Ed.) (name of the book?). Oxford: Learning Forward.

Narkar, P. M. (2013). From Top-down intervention to bottom-up initiative: Teacher development in Nellore. In R. Bolitho \& A. Padwad (Eds.), Continuing Professional Development: Lessons from India (pp. 31-39). New Delhi: British Council.

Nawab, A. (2017). What difference could in-service training make? Insights from a public school of Pakistan. Teacher Development, 21(1), 142-159. doi: 10.1080/13664530.2016.1207094

O’Brien, B. C., Harris, I. B., Beckman, T. J., Reed, D. A., \& Cook, D. A. ( 2014). Standards for reporting qualitative research: A synthesis of 
recommendations. Academic Medicine, 89(9), 1245-1251.

Padwad, A., \& Dixit, K. K. (2013). Multiple stakeholdes' views of continuing professional development. In $\mathrm{R}$. Bolitho \& A. Padwad (Eds.), Continuing professional development: lessons from India (pp. 11-22). New Delhi: British Council.

Power, T., Shaheen, R., Solly, M., Woodward, C., \& Burton, S. (2012). English in action: School based teacher development in Bangladesh. Curriculum Journal, 23(4), 503-529. doi: 10.1080/09585176.2012.737539

Praag, B. V., \& Sanchez, H. S. (2015). Mobile technology in second language classrooms: Insights into its uses, pedagogical implications, and teacher beliefs. ReCALL, 27(3), 288-303. doi: doi:10.1017/S0958344015000075

Richards, J. C. (2017). Teaching English through English: Proficiency, pedagogy and performance. RELC Journal, 48(1), 7-30. doi: 10.1177/ 0033688217690059

Ur, P. (1996). A Course in Language Teaching. Cambridge: Cambridge University Press.

Yazan, B. (2015). Three approaches to case study methods in education: Yin, Merriam, and Stake. The Qualitative Report, 20(2), 134-152.

Yook, C., \& Lee, Y.-h. (2016). Korean EFL teachers' perceptions of the impact of EFL teacher education upon their classroom teaching practices. AsiaPacific Journal of Teacher Education, 44(5), 522-536. doi: 10.1080/ 1359866x.2016.1144171

Zein, M. S. (2016). Professional development needs of primary EFL teachers: Perspectives of teachers and teacher educators. Professional Development in Education, 1-21. doi: 10.1080/19415257.2016.1156013

Zein, S. (2015). Factors affecting the professional development of elementary English teachers. Professional Development in Education, 42(3), 423-440. doi: 10.1080/ 19415257.2015.1005243

\section{Contributor}

Md. Abdur Rouf (corresponding author) works as an assistant professor in English at Jagannath University, Dhaka, Bangladesh. He did his first MA in English Literature and second MA in ELT from University of Dhaka. Currently he is doing his doctoral research at Universiti Sains Malaysia in Malaysia. His research interests include second language teacher education (SLTE), ICT in language teaching, and $21^{\text {st }}$ Century Skills.

Professor Dato' Dr. Abdul Rashid Mohamed is a consultant to the Malaysian Ministry of Education as well as the Ministry of Education of the Republic of Maldives. A senior professor at Universiti Sains Malaysia, he holds a PhD in TESOL from East Anglia University in the UK 